\title{
How Blue Can You Get? \\ B.B. King, Planetary \\ Humanism and the \\ Blues behind Bars
}

Les Back

Goldsmiths, University of London

\begin{abstract}
This article honours the memory of blues musician B.B. King, who died on 14 May 2015 , through focusing on his work and historical performances in prisons. The article situates his concerts inside Cook County jail and Sing Sing within the wider political crisis during the 1970 s surrounding issues of race and class in the American prison system. It suggests the historical resonance of these events can be interpreted through using Paul Gilroy's notion of planetary humanism. The tone of B.B. King's guitar carries both the historical trace of African American experience while at the same time voicing a humanistic sensibility beyond the brutalities of racism and incarceration.
\end{abstract}

Keywords

African American music, blues, Paul Gilroy, B.B. King, planetary humanism, prisons

Part I: 'There's Something about Being in Prison'

Amongst the tributes celebrating the life of B.B. King - who died on 14 May 2015, aged 89 - it was rarely pointed out that this giant of blues guitar gave his most sublime performances behind bars. Overa 25 -year period, B.B. King performed in 47 different jails across America. As he reflected in his autobiography, 'there's something about being in prison'. Never charging a fee, he played the blues inside the prison walls only for the satisfaction of what he called 'touching souls that needed to be touched'. In remembering B.B. King's music and his extraordinary life, I want to foreground this because the ineffable 'something' he indexes, I argue, is a humanist sensibility in his music. In the feel, touch and tone of his guitar we can hear the trace of what Paul Gilroy 
has called a planetary humanism (see Gilroy, 2004, 2010).

He was born Riley B. King on 16 September 1925 on a cotton plantation called Berclair, near the town of Itta Bena, Mississippi. The son of sharecroppers Albert and Nora Ella King, the young Riley was raised by his grandmother from the age of four. During much of his early life he had to fend for himself. He wrote in his autobiography that this early experience of estrangement and loneliness formed him as a person: 'My friendliness might fool you ... But few if any really know me ... Words are not my friends. Music is. Sounds, notes, rhythms.'

While in Memphis, working as a singer and disc jockey at WDIA, he picked up the nickname 'Beale Street Blues Boy', later shortened to 'Blues Boy' and then finally to

B.B. During the 1950s, B.B. King emerged as a key figure in the electric blues, scoring hits with ' $3 \mathrm{O}^{\prime}$

Clock Blues', 'Woke Up This Morning,' 'You Upset Me Baby' and 'Every Day I Have the Blues'.

In 1954, B.B. King named his guitar 'Lucille' after he nearly lost his life rescuing it from a burning dancehall in Twist, Arkansas. It's a story that bears repeating. Two men got into a fight and knocked

over a vat of burning kerosene being used for heating. When B.B. emerged from the burning building holding his guitar he was told that the men were fighting over a woman named 'Lucille'.

Why do blues guitarists name their guitars? Personalizing an instrument makes it individual and perhaps more human. For many players the guitar is their most constant companion. But a blues musician's life is precarious and always on the move. Many guitars have been stolen on the road or pawned when cash is tight. There is something meaningful in the act of naming the guitar, and most bluesmen choose female names.

Baptising a guitar is not just about giving it an identity, making it a 'significant other' and the object of love and devotion. The relationship between musician and instrument is two-way. Hands and fingers wear themselves into the instrument's body. The soul of the player seeps into the fretboard and the guitar also becomes part of the musician.

Lucille has taken the shape of many different kinds of guitar.

The first Lucille was a Gibson

L30 archtop. This guitar was stolen and B.B. replaced it with a Gibson ES 5, like his hero T Bone Walker. However, since the late '50s, Lucille has taken the form of the Gibson 335. 'I've turned to

Lucille - and there have been seventeen different Lucilles - for comfort and relief. Just to pick her up and stroke her settled me down. I put her on my lap and wait until some happy combination of notes falls from her mouth' (King and Ritz, 2011: 130).

The ES 335 became the medium through which B.B. achieved his unique tone. As a young man he loved the sound of the hillbilly steel guitars he heard on the radio. The trace of that 
fascination, and also the sound of delta slide guitar players like his cousin Booker White, echoes in B.B.'s style of vibrato and string bending. You only need to hear one note of B.B. King playing to identify his unique sonic fingerprint.

By the time B.B. King was doing his prison performances in the 1970s, blues was thought to be out of step with black popular taste. B.B.'s manager - Sid Seidenbergtried to broaden B.B.'s appeal, and this was not just with white rock audiences that embraced him. Seidenberg also booked B.B. to play at Mr Kelly's, Chicago's prestigious jazz club on Rush Street, a place where Sarah Vaughn, comedian Bill Cosby and a young Barbara Streisand had performed. This lounge jazz venue would provide the unlikely steppingstone for his history-making performance at Cook County Jail.

\section{Live at Cook County}

In the late '60s and early '70s, a crisis was unfolding in America's prisons. It was driven in part by a shortage of resources, butalso prisons had become inequality factories. They both produced and processed divisions of race and class. At Cook County, the prison population was 90 per cent black, while the prison guards and wardens in control of them remained largely white.

Facing limited resources, the then Deputy Warden of Cook County set up the 'Barn Boss' system, which effectively handed over the internal running of the prison to the inmates. Once the bars on the prison doors were locked, the tiers of the jail were run by whoever was the toughest and most physically intimidating inmate. For the prison authorities, all that mattered was that the prisoners didn't escape. C Richard English, who played a central role in bringing B.B. King to Cook County, remembered: 'There was a very serious level of rapes, and I think the straw that broke the camel's back and caused the administration to change was when a white young man was hanged. They say he hanged himself but they believed the inmates hung him. They abused him so bad that he was probably going to tell. ${ }^{\prime 1}$

In March 1968, black psychologist Winston Moore was appointed Warden of Cook County; in fact he was the first black prison warden in the United States. C Richard English was his Chief Jail Officer, responsible for the internal running of the prison. English came to Cook County from the Illinois State Correctional Department for Youth in Joliet. He was an exranger, paratrooper and retired professional fighter and kickboxer. He immediately recruited a team of over a dozen officers from Chicago's black neighbourhoods, including his boxing team. Many of the members bore names as memorable as any gangster, like 'Smitty' or 'Iron Man' Wallace (English, 2007). He remembered: 'The Sheriff at the time, I mean, he had nothing to lose, he had 
the worst jail in the world. Imean what did he have to lose? It was like do or die.'

The tiers of the prison run by the 'Barn Bosses' and 'Tier Clerks' had to be taken back by 'cracking heads' and through physical force. English's team cleaned out stashes of weapons and confiscated drugs as well as refrigerators full of food. C Richard English reflected: 'You can't do what I did now. Half of that stuff we had to do probably got us put in jail.' Paradoxically, inside the prison, black prison guards had to 'take care of the white guys first. It was like a reversed segregation type situation in the jail because white guys were so outnumbered they were at the mercy of the other prisoners.' However, English said, 'the black guys knew what I was doing', and it was widely recognized that the level of prisoner-on-prisoner violence under the 'Barn Boss' system was out of control.

I asked him if the hiring of black prison guards made a difference to the dynamics with the prisoners. 'Yes sir, it did make a big difference. One of my finest officers was the first cousin of one of the worst inmates. Ihired him and he told me his father was looking for a job. Being a correctional officer was a good job in Chicago - still is. So I hired his father and his brother.'

The black officers were not only tough but they also brought with them the sensibilities of the neighbourhood. English said: 'Although you have to be heavy handedyou also have to know when to stand down and make sure the inmates got what they need to survive.' What is interesting amongst the black leadership of Cook County was their awareness that taking back physical control of the prison was only part of the answer.

Music was central to the strategy for pacifying Cook County. C Richard English was a jazz fan, his favourite artist being the blind English pianist George Shearing. His mother was a school teacher specializing in Englishand music. English developed a sophisticated classification system that kept most prisoners away from the 'hard core tough group'. He also put all the inmates who could play music together in a tier of the prison, and in this section jail bands formed, including rock' $\mathrm{n}^{\prime}$ roll, spirituals, and jazz, with something between 40 to 60 musicians. English broughtstreetentertainers into the prison too, for concerts, and, prior to B.B. King's historic show, jazz singer Ester Phillips performed at Cook County (English, 2007: 69-70).

English had met B.B. King in Memphis several years before the bluesman came to Chicago to play at Mr Kelly's jazz club. By this point Winston Moore was Warden of Cook County. English brought King and Moore together and they hatched a plan to play a concert at Cook County and also record it.

It would not be the first time that B.B. King's music would be recorded live in Chicago. In 1964 he recorded Live at the Regal, which captured his performance in a black theatre in Chicago and 
is widely regarded as a classic blues recording amongst critics and blues aficionados. In his autobiography, King himself is more circumspect, commenting: 'even though the Live album was cool, I've probably played hundreds of better concerts than the one taped at the Regal' (King and Ritz, 2011: 222).

The recording made at Cook County on 10 September 1970 in front of 2117 inmates was truly exceptional. In front of the concrete block used as a stage, wooden benches were set out for 200 female prisoners to sit on while the men stood or sat behind them. It was a hot day by September standards. C Richard English remembers: 'He walked through the crowd and shook hands with the inmates and he gave them autographs. He allowed the inmate band to play with him, including female inmate singers an hour and a half show nonstop.' Twenty-five members of staff volunteered to come in for free on their 'off day' and a hundred officers were on duty. Once the prison band finished playing, the tapes started to roll.

At the beginning of the recording, Jewel LaFontant, a Chicago lawyer, offered a few words of credit to Sheriff Joseph Woods and Chief Judge Power for appointing Winston Moore and for the changes at Cook County. The chorus of boos and jailhouse jeers made the prisoners' feelings clear. B.B. King stepped forward and gave an astonishing performance. It combined the intensity of a
Baptist sermon and the comedy of a vaudeville comedian.

The intensity of his guitarplaying is what left a lasting impression on C Richard English. 'I talked to B.B. a couple of times about that music and he felt a closeness and sympathy for the guys that were locked up and he wanted to really relate to 'em and tell 'em a story .. . especially that song he did The Thrill is Gone. He really got into it with that guitar - not so much with the words but with the guitar music. Looking at the audience, they are feeling the same thing he is feeling.'

Live at Cook County captured the soaring intensity of his playing, the eloquent string bending in his solos that tell a story in musical phrases like the electric trace of a human voice. In his autobiography, Blues All Around Me, he reflected:

Maybe it's the stone walls, maybe the electric fences or the guard towers or the sound of those huge iron doors slamming behind you. There's something final and scary and rock-hard about being inside of a prison. I was a guest performer at the Cook County jail, I'd come to entertain the men, and I couldn't help but feel the oppression. My heart was heavy with feeling for the guys behind bars. It didn't matter that I'd never been in criminal trouble myself. I'd known men who'd gone to 
prison and understood how the circumstances of their lives led them there. It's not that I don't feel for the victims and it's not that I don't believe in personal responsibility. I do. But I worry about the correctional facilities and their capacity to help rebuild souls, rather than destroy them. (King and Ritz, 2011: 257)

C Richard English said that a month after the recording was made, B.B. King returned to the prison. This time it was not to perform but just to catch up with the inmates. The Chief let him roam wherever he wanted to go. B.B. King spent two or three hours in the yard, talking to prisoners and catching up with the musicians in the prison band. King's concert was not the last at Cook County. They hosted monthly shows into the '80s, including blues giants like Bobby 'Blue' Bland, along with soul singers like Aretha Franklin, Isaac Hayes, the ChiLites and the Pointer Sisters. English's own favourite, the blind jazz pianist George Shearing, performed in the jail twice, and even Liza Minnelli performed for the inmates, choosing a 'more bluesy repertoire especially for the occasion'.

'Music is powerful stuff. When you listen to music and you locked up - music kinda put a spell on you in a way', concluded English. 'Music soothes the soul and sends a message.' He continued: 'You take a guy like Marvin Gaye's music What's Going On, singing about that Vietnam stuff. You could stop fights with that type of music. I had a [music] box made for myself so I could be part of the inmate situation and I'd go around and play music for the guys in different places and I'd play Marvin Gaye's What's Going $O n$, and guys would stop arguing and slow down and start dancing.'

\section{Part II: After Attica}

Elsewhere in the United States, the crisis in the penal system remained. By the early'70s American prisons were filling up with activists from a range of politically radical movements. On 9 September 1971, two weeks after the killing of George Jackson at San Quentin, prisoners at Attica prison in upstate New York seized control of part of the prison, also taking hostages. In D-yard, they set up democratic structures to define and voice their concerns, which included the racism from the guards, poor food, and limits on religious freedom and political organization.

By the order of State Governor Nelson Rockefeller, the state police and the National Guard took back the prison in a bloody and murderous operation. As tear gas was dropped, law enforcement officers opened fire indiscriminately in a six-minute fusillade where 4500 rounds were fired, including illegal 'dum dum' bullets that exploded on impact. The hail of gun fire killed 29 prisoners. 
It was falsely reported that the inmates had slit the throats of the hostages. However, the autopsy later showed that 10 hostageshad been killed - not by theprisoners' makeshift weapons but by the same bullets fired by the law enforcement officers that killed the convicts.

In the days that followed there were reprisals and beatings of prisoners by guards. After Attica, the issue of prisons and prison life was put squarely on the public agenda. Over 40 years later, the injustices of Attica are still an open wound. Photographer and filmmaker Bruce Jackson has studied the photographic evidence - some of which was suppressed in the subsequent law suits - and found that some of the convicts were killed at close quarters and not by the rooftop riflemen (Jackson, 2011). One of them - Kenneth Molloy had his eyes blown out with a .357 Magnum hand gun after he was dead or while he was dying. Film footage now available of the aftermath shows a white law enforcement officer holding his clenched fist aloft, saying boldly: 'that's white power' (Kunstler and Kunstler, 2009).

The significance of the Attica revolt is hard to overstate. These events played out on national television, much of it dis-information or just plain lies. John Lennon recorded a song called Attica State that denounced Rockefeller and appeared on the album Some Time in New York City. In December 1971, he performed the song at a benefit concert that took place at the Apollo Theatre in New York for the families of those killed.

This was the context in which B.B. King's prison performances were taking place: their edginess as a well as their joy - is charged by the historical and social forces that coalesced around the prison. As Avery Gordon (2010) has pointed out, it is often forgotten that slavery is still legal in the United States when it comes to prisoners. Legal enslavement is enshrined in the US Constitution's Thirteenth Amendment, pointing to the significance of the history of plantation slavery and the politics of prisons.

The prisoners of Attica seem to reference this in the five demands they issued to the people of America during the revolt; they wrote: 'WE are MEN! We are not beasts and do not intend to be beaten or driven as such. The entire prison populace has set forth to change forever the ruthless brutalization and disregard for the lives of the prisoners here and throughout the United States. What has happened here is but the sound before the fury of those who are oppressed' (http://theory culturesociety.org/les-back-howblue-can-you-get-B.B.-king-planetary-humanism-and-the-bluesbehind-bars-part-two/ - _ftn4; quoted in Wicker, 2011: 319).

No wonder then that B.B. King felt drawn to perform for prisoners and why his performances are loaded with such intensity and historic weight-his guitar is the same sound that was given a name so 
aptly in the statement made by the prisoners of Attica. It cries out for a sense of humanity - even, or perhaps particularly, in the midst of the confinements of the prison.

\section{Thanksgiving, Sing Sing 1972}

The experience of B.B. King chimes with Paul Gilroy's argument for the usefulness of the idea of 'planetarity' to convey a different sense of human experience (Gilroy, 2004: xi). This quality of experience involves both movement and contingency. For Gilroy, the art and lives of musicians - from Curtis Mayfield to Bob Marley - offer clues about ways to think about the link between human life and inhumanities of racism. His sense of planetary humanism aims to link the two and develop an ethics and politics 'capable of comprehending the universality of our elemental vulnerability to the wrong we visit upon each other' (Gilroy, 2004: 4).

Life on the road for B.B. King meant coming into routine confrontation with the limitations of the colour bar manifest in the 'whites only' restaurants and hotels. He toured relentlessly, and in 1956 he played a staggering 342 one-nighters (Taylor, 2015). It was for this reason that B.B. was so proud of his tour bus, the first bought in 1955. The tour bus served as his home from home and shelter from Jim Crow racism. Between gigs there were routine reminders for a travelling musician that, for white society, black people were less than fully human.

On 23November $1972 \quad-$ Thanksgiving Day - B.B. King's tour bus rolled into the small village of Ossining on the Hudson River, 30 miles from New York, and the location of Ossining Correctional Facility, known more commonly as Sing Sing. The prison was notorious for electric chair 'Old Sparky'; it was where high-profile executions took place, including Julius and Ethel Rosenberg - for alleged Cold War espionage - on 19 June 1953. The last person executed in New York state was African American Eddie Lee Mays, for murder, on 15 August 1963.

B.B. King was there to perform as part of a project developed by David Hoffman and Harry Wiland. David Hoffman explained from his home in Santa Cruz, California: 'Attica changed everything - it was like a war inside a prison. Prior to that nobody was really paying attention to prisons around New York state that had real reputations for being notorious, but no-one knew anything about prisons at all. ${ }^{2} \mathrm{He}$ lived close to Sing Sing in Westchester, and with his colleague decided to teach a class on filmmaking and theatre. The culmination of this year-long prison arts project was a concert that would be filmed. This included not only B.B. King but also Joan Baez, The Voices of East Harlem, and jazz comedian Jimmy Walker.

The film B.B. King and Joan Baez Live in Sing Sing is an 
extraordinary document of this 'happening' (Hoffman, 1973). Filmed over two days and with seven camera crews, the film takes the viewer inside the prison from the prisoners' point of view. David Hoffman told me that the star of the film is Tony Pabone, who introduces the film and acts as the concert stage manager. At Sing Sing he was head of the Young Lords, a famous Puerto Rican gang. Hoffman referred to him as 'a spectacular talker and great thinker'.

Hoffman explained that part of what made the performances special was the quality of the sound system and the stage, purposebuilt and well lit: 'B.B. said it was his best performance to date. I don't think he ever beat it', Hoffman remembered. An excerpt from the film was watched 500,000 times on YouTube in the days after B.B. King's death.

B.B.'s guitar playing is nothing short of sublime. The film also capturessmallmoments of human recognition between the performers and the inmates. Before Joan Baez sings a spine-chilling rendition of Bob Dylan's I Shall be Released, she kisses her convict compere on the cheek. The prisoners are rapturous in their response. Then B.B., needing to fill some time while the band changes over, raps with the audience about the difficulties of getting into the prison. He makes light of the fact that one of his band members 'you seem to know very well', implying that he'd done a spell in Sing Sing. A member of the audience asks how that makes him feel. Without missing a beat B.B. replied: 'makes me feel good because he works with me'. The crowd cheers loudly in response.

The film also records the edginess of the guards and the volatile joy of the occasion, as The Voices of East Harlem sang Young, Gifted and Black, or when Joan Baez calls out for the "prisons to be raised to the ground'. The performance is punctuated repeatedly by the numbers of prisoners being read out and ordered to report themselves on the public address system, as if serving as a reminder of the authority of prison. At one point B.B. hands the slip to the compere to read out the number and says in jest: 'I know I am Joan Baez and I ain't gonna kissyer.'

The high point is B.B.'s performance of How Blue Can You Get, a song that is ostensibly a tale of an unappreciativelover. Theblues has always been able to speak to the lonely midnightofhumanemotion, including loss, disenfranchisement, dependency, violence and even death. We learn that the unappreciative lover minimizes and disparages every attempt by the male protagonist to offer and provide things of value. In this stop-time blues, B.B. sings:

I gave you a brand new Ford, she said I want a Cadillac

I bought you a $\$ 10$ dinner, she said thanks for the snack

Ilet you live in my penthouse, you said it was just a shack 
I gave you seven children, now you wanna give 'em back

The affective power of the song is not only to be found in its sexist surface; beneath it too is a cry against a world that also injures and disparages men like the inmates of Sing Sing. A world in which value cannot be bought, like a \$10 dinner or even a penthouse, and this is what gives the final line such a charge. The fugitive power of the blues touches the feeling that, whatever they offer and whatever they do, it will be returned unwanted.

During the finale of his show, B.B. reached out to the audience as he sang 'someone really loves you, guess who?', and as he delivered that finallinehis index fingers point to his own chest. Turning back to the audience, the camera catches a prisoner wiping tears from hiseyes.

‘B.B. King wasn't exactly proinmate, he just wanted them to be treated as human beings', remembered David Hoffman. He said B.B. King 'was not anything but a musician, but there was one thing that he loved to do and that was perform in prison. It is pure humanity. .. . There is a Jewish word for it - it's called a Mensch. He was that ... He always put the people ahead of himself. He was a truly beautiful guy.'

\section{Conclusion: Prison Blues}

As we remember B.B. King we should hear the sound of his guitar's soaring human tone. It is a sound that carries a promise of a different sense of human experience, that contains, as Paul Gilroy writes, the possibility that 'the alienated humanity that was associated with racial divisions could be replaced by a non-racial alternative that suffers, loves, acts, and exercises its will, in reshaping the broken world we have inherited' (http://theoryculturesociety. org/les-back-how-blue-can-you-getB.B.-king-planetary-humanismand-the-blues-behind-bars-parttwo/ - _ftn10; Gilroy, 2010: 118).

I asked David Hoffman if he felt it was still possible to do the kind of prison work he did. 'No, I don't think it would be possible today', he said. 'Prisons have become distant from the American people again. We have a much more harsh image of the criminal.' This is why it is important to think again about the place of the prison in society in a time where the US prison population is over 2.2 million (Gottschalk, 2015).

At Stuart Hall's memorial Bea Campbell recalled a conversation she had about the blues with the great post-colonial theorist and writer. She said that Stuart commented that the 'blues takes you there but doesn't leave you there'. For in this music there is a reckoning with a midnight of the soul and the legacy of exploitation and slavery, but equally the blues contains a joy that speaks out against it.

To end, I have argued that remembering B.B. King's prison performances puts a different inflection on his legacy and its 
cultural significance. Music in prison, during the tempestuous decade of the 1970s, could be a way to pacify prisoners and reward them for good behaviour. It also brought into focus the social and historical forces that were unfolding within the wider society. Inside the walls of the prison, the sound of B.B. King's guitar worked against that sense of being devalued or of having no value. That's how blue you can get. More than this, a sense of humanity was alive in these extraordinary performances, expressed wordlessly in sound and tone that refused the de-basements of racism and that pointed beyond it towards a planetary humanistic sensibility.

\section{Notes}

1. All quotations in what follows taken from a telephone interview with the author on 18 May 2015.

2. All quotations in what follows taken from a telephone interview with the author on 18 May 2015.

\section{References}

English CR (2007) Cook County Jail Barn Boss: Memoir of a Former Jail Warden. CR English.

Gilroy P (2004) After Empire: Melancholia or Convivial Culture. London: Routledge.

Gilroy P (2010) Darker than Blue: On the Moral Economies of Black Atlantic Culture. Cambridge, MA: The Belknap Press of Harvard University Press.

Gordon A (2010) The prisoner's curse. In: Gray $\mathrm{H}$ and Gomez-Barris $\mathrm{M}$ (eds) Toward a Sociology of the
Trace. Minneapolis: University of Minnesota Press, pp. 17-55.

Gottschalk M (2015) Caught: The Prison State and the Lockdown of American Politics. Princeton: Princeton University Press.

Hoffman D (dir.) (1973) B.B. King and Joan Baez Live in Sing Sing. Varied Directions.

Jackson B (2011) Attica at 40. Counterpunch, 8 September.

King BB with Ritz D (2011) Blues All Around Me: The Autobiography of B.B. King. New York: IT Books/ HarperCollins.

Kunstler $\mathrm{E}$ and Kunstler $\mathrm{S}$ (dir.) (2009) William Kunstler: Disturbing the Universe. Arthouse Films.

Taylor M (2015) The man who would be King. Guitarist Magazine (July): 64-67.

Wicker T (2011) A Time to Die: The Attica Prison Revolt. Chicago, IL: Haymarket Books.

Les Back is Professor of Sociology at Goldsmiths, University of London. 